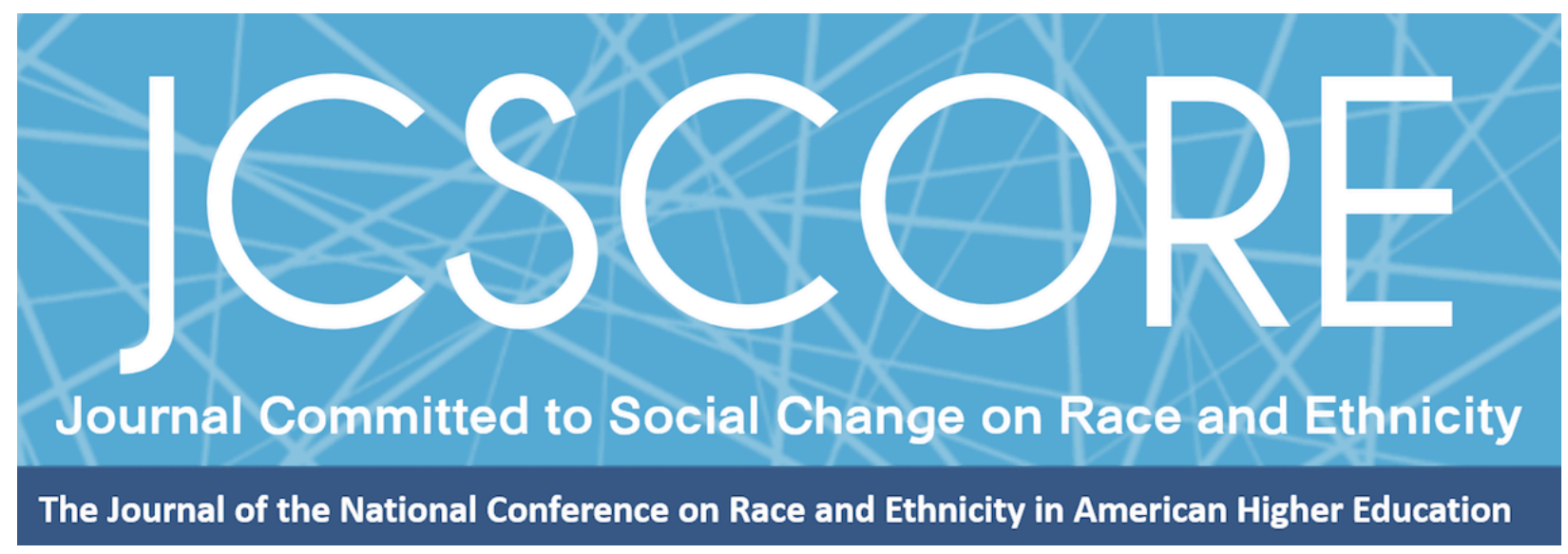

\title{
"I JUST FEEL LIKE I HAVE TO DUKE IT OUT BY MYSELF": HOW LATINO MEN COPE WITH ACADEMIC AND PERSONAL OBSTACLES DURING COLLEGE
}

\author{
Sarah L. Rodriguez \\ lowa State University \\ Charles Lu \\ University of Texas at Austin \\ Beth E. Bukoski \\ University of Texas at Austin
}

Journal Committed to Social Change on Race and Ethnicity

Volume 2, Issue 2 | 2016

Copyright $\odot 2016$ Board of Regents of The University of Oklahoma on behalf of the Southwest Center for Human Relations Studies.

Permission of the Publisher is required for resale or distribution and for all derivative works, including compilations and translations. Quoting small sections of text is allowed as long as there is appropriate attribution. 


\title{
“I JUST FEEL LIKE I HAVE TO DUKE IT OUT BY MYSELF": HOW LATINO MEN COPE WITH ACADEMIC AND PERSONAL OBSTACLES DURING COLLEGE
}

\author{
Sarah L. Rodriguez \\ lowa State University \\ Charles Lu \\ University of Texas at Austin \\ Beth E. Bukoski \\ University of Texas at Austin
}

\begin{abstract}
This qualitative study sought to identify the academic and social challenges that Latino men encountered during college as well as understand how Latino men utilized coping responses to overcome those obstacles. Latino men in this study most often encountered four major academic and social obstacles during their college experience: over involvement with on-campus organizations, academic preparedness, family influence, and building a support system. To cope with these challenges, study participants often chose to cope internally with obstacles, rather than reaching out and utilizing support systems. The men who utilized support systems to cope with their challenges relied mainly on college peers and mentors.
\end{abstract}

By 2060 , projections estimate that Latina/os will comprise $31 \%$ of the total U.S. population (US Census Bureau, 2012). In addition, degree attainment for Latina/os increased by $56 \%$ within the past five years while degree attainment for the overall population increased by only $21 \%$ (Excelencia in Education, 2015). Despite exponential growth of the Latina/o population and the overall gains made in their college access and success, Latinas/os continue to experience lower levels of bachelor's degree educational attainment ( $22 \%$ of Latina/os aged 25 or older), compared to other racial/ethnic subgroups (Asians 60\%, Whites 46\%, and African Americans 31\%;

Excelencia in Education, 2015). Furthermore, Latino men represent a smaller portion of the undergraduate college population and earn fewer bachelor's degrees compared to 
Journal Committed to Social Change on Race and Ethnicity | 2016

Latinas (Excelencia in Education, 2015; Saenz \& Ponjuan, 2009). While Latino men have increased the rate of attainment of associate degrees by $119 \%$ over the past few years, only $14 \%$ of Latino men, 25 and older, have earned a bachelor's or higher (Excelencia in Education, 2015). Furthermore, the educational attainment of Latino men becomes more complicated with attendance at selective, predominantly White institutions (PWIs). Latina/o students at PWIs are often burdened with additional challenges related to sense of belonging, racism, and racial climate (Hurtado, Milem, Clayton-Pederson, \& Allen, 1998; Lu, 2015; Nuñez, 2009). Although college Latino men may be more likely to complete a degree at a selective institution, their intersectional status as male students of color at a PWI presents additional obstacles with which they must cope.

Given the intersections of their multiple identities, Latino men may encounter unique, intersectional experiences in which they must negotiate and cope their college experiences within the context of their racial/ethnic and gender identities. In recent years, researchers have examined college men around issues such as coping, gender socialization, identity development, and masculinity (Bukoski \& Hatch, 2015; Gloria, Castellanos, Scull, \& Villegas, 2009; Harper, 2008; Harper \& Harris, 2010; Lu, 2015; Saenz, Bukoski, Lu, \& Rodriguez, 2013; Saenz, Mayo, Miller, \& Rodriguez, 2015). These foci serve to draw attention to the way gender plays out in unique ways for men of varying ethnic groups.

Although Latina/o students of all genders may encounter similar academic and social college-going challenges, and all men of various genders may also encounter some similar challenges, Latino men experience and cope with challenges in ways often 
Journal Committed to Social Change on Race and Ethnicity | 2016

distinct from their female counterparts and from other men (Gloria et al., 2009; Saenz \& Ponjuan, 2009). The body of literature related to Latino men is sparse (Gloria et al., 2009; Saenz et al., 2013; Saenz et al., 2015; Saenz \& Ponjuan, 2009; Urias \& Wood, 2015), and within this body are glaring gaps related to understanding how Latino men cope with obstacles, particularly at selective, predominantly White institution. Although prior research has examined personal and social factors assisting Latino men with educational success, less attention has been given to the coping responses they use to overcome obstacles (Cavazos et al., 2010; Zalaquett, 2006). Recent scholarship, however, has demonstrated the need for research to explore coping processes, particularly among Latino men in college (e.g., Huerta \& Fishman, 2014; Covarrubias \& Stone, 2014).

The purpose of this qualitative phenomenological research study was to understand the academic and social obstacles encountered by undergraduate Latino men at a PWI and to explore the coping responses of these students as they seek to overcome these obstacles. In order to transform the higher education experiences of Latino men, in depth and nuanced understandings of their experiences must be generated to better inform policy and practice. Phenomenology, therefore, is well suited for this study because it seeks to explore a phenomenon in-depth and to understand the essence of the participants' lived experiences and meaning making; an approach that honors the complex intersectional identities of participants (Padilla-Diaz, 2015). The research questions therefore focus explicitly on participant experiences: (1) What academic and social challenges do Latino men encounter during college? (2) How do 
Journal Committed to Social Change on Race and Ethnicity | 2016

undergraduate Latino men utilize coping responses to overcome academic and social challenges during college?

This study simultaneously enhances the body of knowledge that scholars have concerning Latino men in college as well as extends understanding of how these men utilize coping processes. The study combines interdisciplinary concepts from psychology, sociology, and education to explore the obstacles that these Latino men face in a more robust way and adds a multi-faceted understanding of how these students are making sense of and coping with these obstacles.

\section{Review of the Literature}

Within this section, we will describe the higher education context in which Latino men are situated as well as explore the relevant literature concerning Latino men's educational experiences and the process of coping with challenges while in college. The literature review will serve as a way to demonstrate the need for further research, particularly related to qualitative inquiry, on the coping responses of Latino men in higher education.

\section{Latino Students in Higher Education}

Research has found that Latina/o students must often overcome an abundance of personal and academic challenges in order to enroll and persist within higher education (Carter, Locks, Winkle-Wagner \& Pineda, 2006; Kalsner \& Pistole, 2003), some of which are a result of adapting to cultural differences. For instance, many Latina/o students during their K-12 schooling encounter obstacles associated with low expectations (Davison-Aviles, Guerrero, Barajas-Howarth, \& Thomas, 1999; Zalaquett \& Feliciano, 2004), discrimination (Edwards \& Romero, 2008), self-efficacy (Bandura, 
Journal Committed to Social Change on Race and Ethnicity | 2016

2010), and less rigorous high school curricula (Gandara \& Contreras, 2009). Once in college, Latina/o students found academic adjustment, social relationships, time management, and environmental adjustment to be obstacles to overcome during their college experiences (Hurtado, Carter, \& Spuler, 1996).

\section{Latino Men in Higher Education}

Recent literature has suggested that Latino men students face unique academic and personal barriers that may hinder them from successfully attaining a college diploma (Barajas \& Pierce, 2001; Huerta \& Fishman, 2014; Lu, 2015; Saenz et al., 2013; Saenz \& Ponjuan, 2009, 2011). Studies found that Latino men who successfully matriculate to college are often unused to "help-seeking" behaviors and are discouraged from reaching out to campus resources and communities for support (Gloria et al., 2009; Saenz et al., 2013). Huerta and Fishman (2014) also discussed how Latino college men struggle to conform to highly selective research college campuses due to friends labeling their academic habits, like studying hard or engaging in academics, as acting. Some of these students, therefore, felt that they had dual personas (one on display in college and one on display at home) and had challenges with balancing both roles. Furthermore, Lu's (2015) study found that Latino college men who were failing STEM courses had a disconnect from reality and did not truly believe they would fail until it was too late.

Personal barriers also have key effects on the Latino men's student experiences. For instance, Ford's (1996) study found that Latino boys encounter messages of school resistance as early as elementary school which may pose a threat to school achievement (Covarrubias \& Stone, 2014). School resistance is a way to avoid ridicule 
Journal Committed to Social Change on Race and Ethnicity | 2016

from peers, and a key coping response is to underachieve in school to demonstrate loyalty to peer groups. Research has also shown that Latino families play a major role in adjustment, coping responses, and persistence for Latino college students (Huerta \& Fishman, 2014; Huerta, McDonough, \& Allen, 2014). This influence may come in positive forms of encouragement; however, students also encounter negative familial influences that can ultimately pull them away from pursuing higher education (SuarezOrozco \& Suarez-Orozco, 1995; Saenz \& Ponjuan, 2011). Many families' limited knowledge of the American college system coupled with cultural expectations of male responsibilities to financially contribute to their families also deter many Latino men from enrolling in college (Saenz \& Ponjuan, 2009). In addition, literature on Latino masculinity (Bukoski \& Hatch, 2015; Huerta \& Fishman, 2014; Levant \& Kopecky, 1996; Saenz et al., 2013) has shown that pride and machismo may also have complex effects on how Latino men students navigate and cope with the collegiate environment. As such, exploring coping responses to the unique academic and personal obstacles that Latino men face in higher education may provide new implications on how college structures may support these students.

Numerous studies (Halx \& Ortiz, 2011; Saenz \& Ponjuan, 2009; Solorzano, Villalpando, \& Oseguera, 2005) have found educational structures preventing Latino men from successfully attaining a college degree. For example, discriminatory educational practices may be adversely affecting the way Latino men view the education system, resulting in low enrollment in postsecondary institutions (Saenz \& Ponjuan, 2009). In addition, limited financial, social, and cultural capital may further hinder Latino men's aspirations of completing college (Schwarz \& Guido-Dibrito, 2009). 
Journal Committed to Social Change on Race and Ethnicity | 2016

Halx and Ortiz (2011), for instance, found Latino men students dropped out of high school largely because they felt teachers and administrators did not value their efforts to become academically successful. While empirical studies have been published on coping mechanisms adversely affecting academic performance such as sabotaging achievement, failing to do assignments, and refusing to be in gifted education and advanced-level classes (e.g., Ford, 1996; Fordham \& Ogbu, 1986; Grantham \& Ford, 2003), few studies have explored how coping mechanisms can be used to overcome academic and personal obstacles.

\section{Theoretical Framework}

The present study examined the academic and social challenges that Latino men encountered during college and how Latino men utilized coping responses to overcome those obstacles. To address our research questions, we used a theory of psychological stress and coping developed by Lazarus and his colleagues over a number of years and expounded upon by others, including Phinney and Hass, who focused their study on ethnic minority students (see Coyne \& Lazarus, 1980; Lazarus, 2000; Lazarus, 1981; Lazarus \& DeLongis, 1983; Lazarus \& Folkman, 1984a, 1984b; Lazarus, Kanner \& Folkman, 1980; Phinney \& Haas, 2003). According to Folkman and Lazarus (1980), coping processes refer to

what the person actually thinks and does in a particular encounter and to changes in these efforts as the encounter unfolds during a single episode or across episodes that are in some sense part of the common stressful encounter. (p. 224)

Attempting to identify individual strategies as more or less effective may be impossible because the success of coping processes is highly circumstantial and reliant on context and personal reactions. However, coping proactively is more likely to be effective in 
Journal Committed to Social Change on Race and Ethnicity | 2016

response to events seen as controllable whereas other, more reactive approaches, may be more applicable in situations where the individual feels the events are out of their control (Compas, 1998). Within coping theory, social support also serves a positive role in an individual's ability to cope with obstacles (Pierce, Sarason, \& Sarason, 1996).

More specifically, Phinney and Haas (2003) identified five prevalent responses within the coping processes of ethnic minority students. Students within their study often sought to be proactive, taking direct action to manage their circumstances and seeking support from others in order to overcome obstacles. Learning to accept and normalize obstacles as well as positively reframing obstacles were also strategies that students employed during coping. Finally, students also chose to avoid or distance themselves from obstacles in order to relax or forget about challenging circumstances.

Coping has recently been used to explore academic self-efficacy and outcomes in higher education; for example, Xuereb (2015) found that academic resourcefulness and coping strategies were negatively associated with self-doubt. Similarly, Covarrubias and Stone (2014) found that a coping strategy called self-monitoring had a positive correlation with academic outcomes for Latino men students. The same study found no correlation between self-monitoring and academic outcomes for Latinas or White men, which suggests that specific coping strategies are particularly important for Latino men students. Nevertheless, scholars continue to face difficulties in defining and measuring effective coping, particularly when obstacles are ongoing or multi-faceted (Lazarus, 2000; Somerfield \& McCrae, 2000). As a response to these difficulties, scholars have emphasized the need for research designs, particularly qualitative 
Journal Committed to Social Change on Race and Ethnicity | 2016

research designs, that are dynamic and able to capture the complexity of the coping process (Folkman \& Moskowitz, 2000; Lazarus, 2000).

Theory related to psychological stress and coping, developed by Lazarus and his colleagues over a number of years was selected to frame the study due to the focus on understanding the processes related to coping and its considerations of the multiple ways in which an individual may cope with a particular obstacle. In particular, this study sought to build on prior understanding of specific coping processes, focusing specifically on the coping processes of Latino men in college.

\section{Methodology}

This phenomenological study investigated the coping responses Latino men students used to overcome academic and personal challenges. This research design provided an in-depth and nuanced description of particular phenomena, in this case, Latino men's coping responses (Moustakas, 1994). As a research design, phenomenology is a departure from previous studies of coping responses because it utilizes the participants as informants on their own lives, focusing on their subjective and lived experiences (Moustakas, 1994). Most studies regarding coping processes have been quantitative, requiring students to respond within a predetermined set of answers. Using a phenomenological design, which emphasizes not only the experiences participants have but also how they make meaning of and process those experiences, positions this study as an enhancement to the existing literature (Padilla-Diaz, 2015). Coping processes are a series of meaning making decisions, which make phenomenology a good fit for the research questions and purpose of this study. In addition, phenomenology, which seeks to understand the essence of the phenomenon 
Journal Committed to Social Change on Race and Ethnicity | 2016

(Moustakas, 1994), will add more depth and nuance to our understanding of Latino men's coping responses and how they used coping tools to overcome college obstacles, thus enhancing our ability to provide recommendations for policy and practice.

\section{Site and Participant Selection}

This study took place at a large, urban public university in the southwest region of the United States. The institution is predominantly White, research-intensive, and highly selective in its admissions process. This site has an undergraduate population of over 38,000 students, approximately $20 \%$ of whom identify as Hispanic or Latina/o. As a result of the university's size and sizeable endowment, it is equipped with a variety of resources available to students coping with academic and personal obstacles. Academic resources such as tutoring services, supplemental instruction, and noncognitive coaching as well as resources aimed at personal or social issues such as multicultural centers, advocacy groups, and mental health centers are widely available and advertised on campus.

In order to engage in the study, we identified participants through purposive sampling (Padilla-Diaz, 2015) and they had to meet the following three criteria: (a) self-

identified as a man, (b) self-identified as Hispanic or Latino, and (c) enrolled full-time at the research site university. Participants in the study (see Table 1) were from a variety of classifications (from freshman to senior) as well as from a variety of majors. Most students identified as first-generation college students and possessed family origins from Mexico. Initial invitations to participate were sent via email to eligible students using university list-serves obtained from various administrative gatekeepers. 
Journal Committed to Social Change on Race and Ethnicity | 2016

\section{Data Collection}

The research study included the perspectives of 10 Latino men in the form of both interviews and a focus group (Bradbury-Jones, Padilla-Diaz, 2015; Sambrook, \& Irvine, 2009; Kitzinger, 1994; Moustakas, 1994; Seidman, 1998). All students participated in two one-on-one interviews; five of those students also participated in a focus group (see Table 1). This created a rich dataset to understand participants' processes and experiences.

The two one-on-one interviews explored the types of obstacles faced by Latino men as well as the manner in which they coped with those obstacles. The first interview focused on their overall pre-college and college experiences and asked participants to provide recommendations for coping to other students and advice for administrators. The second interview included follow-up questions from the previous interview and targeted questions regarding coping responses and support systems. The study also included a focus group consisting of five Latino men students. Focus groups in phenomenology are becoming more common as researchers have embraced that "[the combination of focus groups and phenomenology] might actually be advantageous" [emphasis in original] (Bradbury-Jones et al., 2009, p. 667). The focus group allowed participants to engage in discussion about their shared meaning, anecdotes, and gave participants a space to comment on each other's experiences. The major goal for focus the group was to explore major findings from previous interviews with Latino men to provide greater context for, reinforce, or refute these findings. Interviews and the focus group were conducted face to face, lasted approximately one hour to an hour and a half each, and were digitally recorded and transcribed verbatim (Creswell, 2013; Maxwell, 
Journal Committed to Social Change on Race and Ethnicity | 2016

2013). During data collection and analysis, the researchers also engaged in bracketing, common to phenomenological analysis, wherein we set aside our presumptions in order to delve deeply into the interview and focus group experience and resultant data to understand the essence of the experience and where moments of common ground and distinction occurred among the participations (Padilla-Diaz, 2015).

\section{Data Analysis}

Once all recordings were transcribed and loaded into the qualitative data analysis software, the research team created a codebook. The research team used initial etic codes derived from coping theory and supplemented with additional etic codes in a small sample of transcripts (Maxwell, 2013). Throughout codebook creation, team members reviewed transcripts and met to exchange ideas on relevant codes and then, ultimately, establish the final analysis codebook.

Once the codebook was established, each transcript was read several times and electronically coded for specific topics related to coping with academic and social obstacles. Each researcher used the codebook in order to focus the analysis; however, they also identified significant ideas and illuminating quotations, incorporating additional emic codes throughout the analysis process to probe the data further. During this stage, the research team engaged in memo writing activities and met frequently to discuss significant patterns, possible explanations, and alternative explanations for the data. The researchers engaged in a process of explicitation to investigate the components of the phenomenon while concurrently maintaining focus on the context in which the participants live and study (Hycner, 1999). This is a shift away from more traditional analysis techniques, which require the researcher to break the phenomenon into parts, 
Journal Committed to Social Change on Race and Ethnicity | 2016

and this technique allowed the researchers to stay situated in the holistic worlds of the participants as they came to understand the constituent parts of the phenomena (Hycner, 1999).

\section{Limitations}

As with all research, several limitations existed for this study. The study is limited in its investigation of a unique type of research site. As a large, urban, researchintensive, highly selective, predominantly White four-year university in the southwest, Latino men in this study may experience obstacles and coping processes specific to their educational context. For example, students within this university experienced greater challenges related to feelings of academic under-preparedness and a heightened sense of competition from peers. They also felt that the faculty members were generally more invested in their research than their teaching. Furthermore, the context of the predominantly White institution was often in stark contrast to their predominantly minority high schools and home communities.

This study also focused on the perspectives of Latino men who were traditionalaged, mostly of Mexican family origins, who were beyond their freshman year of college. Therefore, these findings may not be transferrable to post-traditional students, Latino men who possess origins from other countries, or students in their first-year of college. Although information gathered from this study adds to the depth of knowledge regarding Latino men's coping responses, results may not generalize to all Latino men within the population.

\section{Findings}


Journal Committed to Social Change on Race and Ethnicity | 2016

Utilizing the theory of psychological stress and coping developed by Lazarus and his colleagues over a number of years and expounded upon by others, including Phinney and Hass, who focused their study on ethnic minority students (see Coyne \& Lazarus, 1980; Lazarus, 2000; Lazarus, 1981; Lazarus \& DeLongis, 1983; Lazarus \& Folkman, 1984a, 1984b; Lazarus, Kanner \& Folkman, 1980; Phinney \& Haas, 2003), this study sought to explore the academic and social challenges Latino men encountered in college and to understand how these men utilized coping responses to overcome those challenges. Latino men in this study most often encountered four major academic and social obstacles during their college experience: over-involvement with on-campus organizations, academic under-preparedness, complications with family and the college experience, and struggling to build a support system. To cope with these challenges, study participants often chose to cope internally with obstacles, rather than reaching out and utilizing support systems. When coping internally, Latino men reactively reflected on their challenges as well as proactively refocused themselves on long-term goals through positive reframing and normalization and acceptance of challenges. The men who utilized support systems to cope with their challenges proactively called upon college peers and mentors.

\section{Latino Men's Academic and Social Obstacles}

We parsed our findings into two main sections. This section focuses on academic and social obstacles while the next section focuses on coping strategies. Latino men in this study most often encountered four major academic and social obstacles during their college experience: (1) over-involvement with on-campus organizations, (2) academic 
Journal Committed to Social Change on Race and Ethnicity | 2016

under-preparedness, (3) complications with family and the college experience, and (4) struggling to build a support system.

Over-involvement with on-campus organizations. Several of the Latino men in this study found that they were overly involved with on-campus organizations. All the students in the study were full-time students, involved in multiple on-campus organizations, and were often pushed to their limits in terms of time management. For Estani, this over-involvement meant fewer hours sleeping and the desire, but not the intent, to cut back on involvement:

this past week [I was up] 7 days a week, [until] 3 or 4 in the morning... I'm just running on adrenaline. So, I like it, but at the same time it's exhausting....My mentality is, "Well you have to cut back on something." And for me it's like, [l'll]...cut back on sleep.

Over-involvement was often the result of a student's intense desire to enroll in difficult course loads in preparation for graduate school or careers as well as a tendency to take on leadership positions in order to affect meaningful change in their often identity-based organizations (e.g. Latina/o, LGBTQIA). It was not unusual for these students to manage 18-hour days filled with several classes, meetings, and events. While the coping literature signals these support-seeking behaviors as a positive, this overinvolvement often translated into tired, frustrated, and overextended students who, despite the strain, continued to engage in such behavior. They did so out of feelings of responsibility to their Latino ethnicity group and/or personal obligation to utilize their knowledge and leadership talents. Intersectionality of specific ethnic group affiliation and sexual orientation, in particular, were driving students to prioritize "support-seeking" over self-care and accepted and normalized their over involvement, and hence their exhaustion and frustration. 
Journal Committed to Social Change on Race and Ethnicity | 2016

Academic under-preparedness. The second category of obstacles for these students related to issues of academic under-preparedness. Most of the Latino men in this study were first-generation college students from a low socio-economic background, which limited their access to a more rigorous high school curriculum and college preparation strategies. Students often struggled with course loads and panicked at the realization that their level of academic work failed to meet the expectations put forth by their professors. Students noted difficulty coping with the demands required of this elite, research-intensive university. As Carlos recounts,

At first I was disappointed, I was kind of mad, angry, frustrated, like "Why couldn't I have been better prepared?" But I don't know, I guess I just also accepted that and I was like, "I need to work a little harder."

Despite being admitted to this institution, Carlos felt as though he was not prepared for the academic rigor he encountered. However, rather than focusing on how the system had ill-prepared him, he internalized his lack of preparation and sought to work harder in order to be successful - a way of accepting challenges as normal for his specific experiences and context; this helped him move past the frustration and work harder to achieve his goals.

Complications with family and the college experience. The third category of obstacles related to complications with family and the college experience. Students often deliberated over how much information to filter from their families as well as how much influence their family's opinion should have on their college decision-making processes. Furthermore, some students found themselves distancing their families and former lives from their newer collegiate lifestyles, a reactive coping response common when students are seeking to relax and forget about a challenge. 
Josue, for example, came out as gay during college, purposefully separating collegiate life from family life, even taking steps to hide his gay identity when he visited home:

Having to sit down and tell them and have them understand is completely different than them knowing just through my actions or my manners. That being said, when I go home, I kind of tone it down a lot. So that's something I've personally dealt with; it's having to go home and resort to my old ways and not be who I am all the time.

Josue was reluctant to "sit down" and tell his parents about his sexual orientation, so he was often forced to adopt the traditional heterosexual norms rather than just be himself. Indeed, family interactions and related obstacles often highlighted differences between the students and their families in terms of academic achievement level, social norms, and social and professional goals.

Struggling to build a support system. The fifth category of major obstacles for these men related to the process of building support systems. Proactive coping responses, such as seeking a support system, are usually more effective in helping students work through challenges, and this was an area where many participants struggled. Prior to college, many students relied exclusively on family as a main support system; however, the transition to college left them without an immediate support structure and forced them to seek outside assistance. When asked about whether individuals in the college setting are generally supportive, one student, Enrique, responded, "I don't reach out very often so I wouldn't know...I don't want to be that person, that annoying person." All students in this study encountered obstacles in building friendships and finding mentors, and struggled to build a strong support system once on campus. Students often cited the size of the university and a difficult college 
Journal Committed to Social Change on Race and Ethnicity | 2016

transition as reasons for their difficulty in building a support system initially, but highlighted student organizations and university-sponsored initiatives as ways in which they finally built a support system.

\section{Utilizing Multiple Strategies to Cope with Academic and Social Obstacles}

During their college experiences, the men within this study were asked to cope with a variety of challenges related to their transition to a college campus as well as their ability to thrive in that new environment. This section centers on how the men within this study coped with identified academic and social obstacles during their college experience. These men utilized two predominant ways in which to cope with academic and social obstacles: internally, utilizing reflection and focusing on long-term goals, and externally, utilizing and building support systems. There was, however, a clear preference for choosing to cope internally with academic and social obstacles through a series of coping responses focused on reactive reflection and proactive reframing to focus on long-term goals. Meanwhile, fewer men chose to tackle obstacles externally and proactively by utilizing and building support systems with their college peers and mentors.

Coping internally: Reflection and focusing on long-term goals. Most of the men in this study chose to internally cope with academic and social obstacles by reactively reflecting on their challenges as well as proactively refocusing themselves on more long-term goals, rather than solely focusing on the present, short-term challenges. For most of the participants of this study, the process of coping with academic and social obstacles was intensely personal and, in many cases, self-contained. When students faced overcoming obstacles, students used a variety of responses, including 
Journal Committed to Social Change on Race and Ethnicity | 2016

talking themselves through multiple options, deliberating over issues of time management, and encouraging themselves to continue despite their circumstances. Rather than turn to an outside support system, several of the Latino men prided themselves on engaging in self-reflection which evaluated their strengths, weaknesses, and plans for the future. This can be considered a reactive coping response as it usually happens after the challenge has been experienced or first confronted, but it can also be considered proactive as students learn to work through foreseeable challenges. Our participants coped in both ways, initially reactive and then more proactive after they normalized and internalized some of the challenges they confronted.

As the title of this paper suggests, most Latino men felt as though they were undergoing a siege within themselves: "I just feel like I have to duke it out by myself." Within his statement, Estani sums up a familiar feeling expressed by many of the men within the study. Similar to other Latino men within this study, Estani chose to "duke it out" with himself, rather than reaching out to others for support in the coping process. His reference to "duking" it out with himself signaled a feeling of competing values or perspectives within his struggle as well as connected his internalization of struggle with a sense of violence or fighting within himself. This is a unique kind of reframing that, as it utilizes norms of masculinity more similar to machismo, may not be positive or productive for students.

At the same time, in an effort to cope with mounting pressure from academic and social obstacles, Latino men often tended to shift their attention away from current problems in order to refocus on long-term goals (e.g., graduation, financial security, 
Journal Committed to Social Change on Race and Ethnicity | 2016

supporting a family). Carlos, for example, discussed how he focused on the big picture, not the short-term obstacle:

I'm really a big picture kind of person...so the way that I overcome obstacles is to tell myself this is small compared to something big. So that's the way that I go through it...So it's like it gets really small so it's like you can do this.

Carlos and several other participants expressed the desire to wait out the short-term difficulty, choosing to focus on larger issues instead of focusing on the short-term challenge. In this way, small, daily challenges became insignificant when compared to the "big picture" of his goals. This kind of reframing helped students put their challenges into a broader perspective.

Many of these students focused on goals that were two-fold, benefitting self and family interests or self and mentoring interests. This coping response was often employed immediately; by placing their sights in the future, Latino men students were able to accept these obstacles as a temporary and normative part of the collegiate academic process as well as assure themselves that their efforts were not in vain. For some students, the positive outcome was more direct and tangible, such as the degree itself or the job to be attained after college. One student, Enrique, described it like this: "I try to look forward. I try to look like I know I'm going to get out of it, whatever this is." Within his interviews, Enrique maintained that his manner of coping was to set his sights beyond the present obstacles in order to focus on his future, an example of proactive normalization of challenges. Even though he described a typical day as "exhausting" and his college life filled with "so much work," he continued to shift his focus from the short-term sacrifices and struggles to the long-term benefits associated with a college education. For others, it was more indirect or abstract, such as positive impact of the 
Journal Committed to Social Change on Race and Ethnicity | 2016

degree on their family, or Antonio's "idea of knowing that I could do something bigger than myself. That I could understand the old dynamics of my life through the studies that academia offered. That was something important for me."

For some students, family and future prospects influenced the process of coping via shifting of their focus from short-term obstacles to long-term inspirational goals. By clinging to the idea that their families might take pride in their accomplishments and benefit from their status as degree-holders, these students came to accept that the obstacles they encountered were both a normative part of the college process and "worth it" in order to make their families proud and help them in the future. There was a close connection between coping processes and a need to complete one's college education for the men in this study. Gilberto's family, for example, enabled him to cope with the immediate academic and social obstacles he faced during college. He clung to this mantra: "I knew why I was doing this. I was doing it for my family." Not only did family serve as an inspiration to Gilberto, with their struggles and sacrifices made in order for him to have a college education, but they also served as a representation of a long-term plan that he had for success and giving back to his family.

Coping externally: Utilizing and building support systems. While the majority of Latino men in this study kept their academic and social obstacles a private matter, some sought to involve their families in the coping process while others proactively branched out and built "logical families" from college peers and mentors in order to develop a sense of belonging on their college campus and create a family-like environment where they felt supported. Families, as a part of the coping process support system, could demonstrate unwavering support and solidarity with their student. 
Journal Committed to Social Change on Race and Ethnicity | 2016

Other students, finding it difficult to navigate the coping process with their families, who often were not college-graduates or had little familiarity with the college-going culture, felt more comfortable seeking college peers and mentors who could commiserate with their challenges and provide active advice for overcoming academic and social obstacles within the college setting. For those men who did choose to utilize and build support systems for coping, biological family was often cited as only a small part of their support system. The bulk of their coping processes and support efforts were shared with individuals who were on-campus and had intimate knowledge of the college-going process. Antonio, for example, was supported by an intimate group of peers and mentors who, acting as his on-campus family, helped him cope with the academic and social obstacles that he faced during college.

Antonio fondly described his peer group as four to six fellow undergraduate students with whom he had connected on multiple levels. Connecting through similar socio-economic and ethnic backgrounds, Antonio and his peers shared many of the same experiences while growing up and struggled to adjust to the academic rigor and social expectations of college life. Reinforcing this connection, he often referred to the plural "we" of his peer group, rather than himself as an individual, when he talked about coping with college obstacles. As he neared graduation, he reflected, "Yes, a support system [is what] they gave me...finding that friendship was very important in college, those friend networks." When probed about why he found those relationships so important to coping, he highlighted the role that his friends took in substituting the support his family was once able to provide him. Although he was very close with his family, often turning to them when coping with obstacles, he admitted that distance and 
Journal Committed to Social Change on Race and Ethnicity | 2016

infrequent visits made his reliance on friendships much more central to his coping processes:

I didn't see [my family] for a year because I could not see them...that's why my friends are so important. Like I tell you, that's why if I didn't have them, I don't know what l'd do because I don't get my family a lot.

Antonio indicated the difficulty of being separated from family and how friends, though not a complete replacement, served as key support. These friends were almost constantly present and undergoing similar pressures and obstacles, so they had the ability to sympathize with Antonio's obstacles and offer informed advice. The disconnect Antonio felt with his family encouraged him to build strong relationships with friends and utilize them in the coping process.

Unlike Antonio, other Latino men expressed their parents played a key role in coping with college stress by providing unconditional support throughout the process. Josue remarked:

[My parents] don't even know, they don't even realize how much they've given me because they're just like, 'Oh we're going to support you. We don't know what you're doing but go ahead and do it, just do it.'... tell myself, 'You know what? It's always going to be okay. Don't worry.' My parents will always be there no matter what.

Though Josue, like most of the other students in this study, was a first-generation college student with parents who did not attend college, his parents still supported his endeavors and sought to support him in any way they could. Josue's parents, as evident through his statement, were committed to seeing him complete his college experience, even though they did not understand the process of what he was doing. Whether it was emotional or financial support that he needed, Josue continued to utilize his family as a means of coping with obstacles by talking with them on the phone 
Journal Committed to Social Change on Race and Ethnicity | 2016

frequently and visiting them as often as possible. Josue had the confidence and support needed to encounter myriad obstacles because "no matter what" his parents were there.

\section{Discussion \& Implications}

This study sought to identify the academic and social challenges that Latino men encountered during college as well as to understand how Latino men utilized coping responses to overcome those obstacles. Latino men's intersectional identities led them to experience a variety of challenges related to both their academic and social life. In order to cope with these challenges, the men in this study often chose to cope internally with obstacles, rather than externally through support systems. Most Latino men internalized challenges through self-reflection and focus on long-term goals. The Latino men who built and utilized support systems to cope with their challenges relied mainly on college peers and mentors, with some Latino men also relying on their families for support.

Our findings regarding the academic and social challenges of Latino men support several ideas already present in the literature, including the challenge of adapting to a demanding academic context (Hurtado, Carter, \& Spuler, 1996) and the negative influence of attending a less rigorous high school (Gandara \& Contreras, 2009). Likewise, the saliency of culture remains a key aspect of the experiences of Latino men in higher education (Cammarota, 2004; Zarate \& Gallimore, 2006). In addition, while our study supports the work of Gloria and colleagues (2009) and Saenz and colleagues (2013) that Latino men often have difficulty with academic "help-seeking" behaviors, our study adds an important dimension to this work. Though Latino men may be reluctant to 
Journal Committed to Social Change on Race and Ethnicity | 2016

seek external coping mechanisms of the institution and prefer to cope internally, they did at times seek support of culturally congruent peers, often accessed through institutionally sponsored organizations. However, over-involvement in such organizations complicated the relationships that many of the men had with those organizations.

This study also adds nuance to the work of Covarrubias and Stone (2014), who found that self-monitoring positively correlated with academic outcomes for Latino men students. We add a unique intermediary element to understanding this finding. While our participants did engage in self-monitoring, it did not affect their behavior in any way - many remained overextended and overinvolved in campus and social activities. And our participants were unlikely to pull back even when their self-monitoring revealed they were overly involved. In addition, the coping literature (Compas, 1998) cites reactive coping strategies such as distancing or avoidance as less helpful, but some of participants successfully used distancing to help them cope with new disjoins with their families, particularly our gay participants. This suggests more research is needed to understand how unique intersectional identities (sexual orientation, gender expression, immigration status, nationality, etc.) within the Latino men subgroup use reactive and proactive coping strategies.

Our study also adds to the research on the role of family for Latino students (Huerta \& Fishman, 2014; Huerta, McDonough, \& Allen, 2014). Similar to the literature, which holds both positive and negative influences, students in this study focused on the complicated ways family influenced their coping processes, and the kind of influence which varied by intersectional identities regarding sexual orientation. Thus, while family 
could be difficult to utilize within the coping process, particularly for gay participants, some Latino men in our study also cited their family as helping them cope by focusing their attention on the long-term familial benefits of their education. Although the majority of the men from this study felt support from their families, they also contended that the cultural, social, and financial capitals their families had to offer only extended so far. While some Latino men retained strong support systems from their families, others sought support for coping from logical families. As such, our findings indicate that many of these men could have benefitted from additional peer and institutional support systems to help them learn time management, commitments, and identify a more comprehensive and professionally oriented support system.

Our findings also suggest that Huerta and Fishman's (2014) discussion of dual personas relates to the way men in our study may be making sense of their family and college selves. While some men were able to move back and forth from home to school easily, others felt these worlds were in conflict at worst and inconsistent at best. For example, participants with additional salient intersectional identities, specifically some of the men who identified as gay, changed their personas when they went home to their families to fit with masculine ideologies and archetypes. Utilizing a Du Boisian dual consciousness or borderland (Anzaldua, 2012) framework in future studies may enable exploration of this phenomenon to better explore how additional intersectional identities influence Latino men's coping processes. We suspect further identities such as immigration status might have an impact as well.

Finally, we suspect that concepts of maschismo, or exaggerated Latino male pride, and masculinity played into participants' over-involvement on campus and 
Journal Committed to Social Change on Race and Ethnicity | 2016

relationship to peer groups as well as the way these students chose to cope with academic and social obstacles (Bukoski \& Hatch, 2015; Huerta \& Fishman, 2014;

Levant \& Kopecky, 1996; Saenz at al., 2013, 2015). Previous literature on Latino masculinity (Bukoski \& Hatch, 2015; Huerta \& Fishman, 2014; Levant \& Kopecky, 1996; Saenz et al., 2013) has shown that pride and machismo may also have complex effects on how Latino men students navigate and cope with the collegiate environment. The way some participants internally reframed their challenges as fighting with themselves is a particular instance of the influence of masculinity on the coping responses of Latino men that warrants further investigation. Future research may seek to explore the relationship between coping and masculinity more explicitly.

\section{Significance}

Many of the Latino college men who participated in this study were doing school related activities between 10-18 hours per day. The participants not only felt like they had to "duke it out" on their own, but they romanticized overexertion as though it was a badge of honor. They spoke proudly about the competitive nature of college, complex academic projects, and working through sleepless nights. Although the majority of the participants recognized that this lifestyle was not a healthy one, few discussed making an active effort to change it. This supplements the literature on machismo because the participants demonstrated a love-hate relationship with being busy. On one hand, they felt like the lifestyle was exhausting but on the other hand, demonstrating overexertion was a marker of masculinity for them. Since many of them felt pressure to financially contribute to their families but were not able to because of school, staying busy and 
Journal Committed to Social Change on Race and Ethnicity | 2016

talking about how busy they were felt like the next best thing to contributing back to their families.

In addition to talking about how hard they worked, many of the participants also talked about how they would cope with their stressors by "working harder." Throughout the interviews, though, it became clear that working harder often equated to spending more time reading, doing homework, and completing projects. The majority of the men in the study only thought about adding time to their work; few discussed how to cut their work to be more efficient. Furthermore, none of the participants had a concrete plan that they had built formally to better cope with their stress. Rather, their coping mechanisms seemed to be purely reactive and focused on the short-term instead of preventative and focused on the long-term. Future studies may want to examine how Latino college men are actually spending their time on their academic and career goals that probe deeper into what "working harder" really means.

The participants in this study also focused on competition, both with themselves and with their peers. When participants discussed "duking it out" on their own, they felt like they had to compete with themselves to be their best version. Many talked about "being their own person," "having their own experiences," or "making it [their] own way," all of which were founded in individualistic narrative and proving they could do it on their own. Similarly, their narratives about peers focused on comparing themselves to others or "one-upping" friends that they felt were of similar caliber as them. At the same time, participants seldom discussed collaborating with their friends or classmates citing that they learned better by going it alone. To address the potentially destructive effects of internalization and competition, college academic departments may want focus on 
Journal Committed to Social Change on Race and Ethnicity | 2016

building a collaborative spirit among students, particularly among Latino men, as they face unique racial, ethnic, and gender identity experiences which may magnify feelings of internalization and competition within the college setting which influences coping with obstacles.

\section{Implications for Future Research}

Though this study relates to the broader literature on Latino college men, it is merely the beginning of what should be a larger body of work seeking to understand the Latino mens' coping responses, especially as they vary within this group. Further research in this area may focus on extending this work to include in-depth analysis of multiple years of the Latino student college experience and an explicit focus on masculinity. Another area for research may be to examine the coping responses of Latino men students who have dropped or stopped out; they could provide insight into the ways that failed coping might have contributed to their departure. In addition, researchers may also seek to expand this study to include the perspective of Latino student family members or logical family members. This approach may provide a more detailed understanding of the complex relationship Latino students have with their families and communities and how they perceive the college experience and students' coping responses. Lastly, this line of inquiry may also benefit from a more nuanced approach emphasizing as gender, first-generation status, immigration status, and/or socio-economic level of participants, yielding valuable insight into each intersectional subgroup's coping.

Implications for Policy \& Practice 
In order to transform the lives of Latino men in higher education, this study offers several areas in which policy makers at the institutional level might improve how they interact with and support Latino men. To encourage healthy coping processes, institutions should re-examine their policies regarding mental health services and academic remediation. Within this study, few students mentioned utilizing on campus resources, such as mental health services, to cope with their obstacles. Streamlining these types of services and promoting their use as a healthy, normative part of college may increase the likelihood of students utilizing such services to cope with their obstacles, particularly given how responsive our participants were to engaging in "normal" college behaviors. College mental health centers may also want to normalize the use of mental health services specifically for men of color, given the masculine ideologies and archetypes that were observed in this study. To normalize counseling services for men, counseling centers should partner with academic departments and student services that "fit" into masculine ideologies (e.g., Athletics, Rec Sports, Engineering departments) to provide satellite spaces where college men typically frequent. In addition, many university mental health centers provide services and workshops catered toward one dimension of identity. The authors suggest that university counseling centers expand their services to intersectional dimensions of identity and begin providing outlets and dialogues where Latino men can discuss their triumphs, struggles, and experiences.

Latino men could also benefit from extended mentoring experiences. The opportunity to communicate with older students, professionals, and staff would give Latino men more perspective on how common it is to change academic pathways, 
Journal Committed to Social Change on Race and Ethnicity | 2016

majors, or even career aspirations. In addition, exposure to administrators and faculty who understand complex institutional structures and politics would help Latino men understand their choices and give them the cultural and social capital needed to successfully navigate higher education. There are limited Latino men available for such mentorship roles on college campuses, but institutions should leverage constellation mentoring (van Emmerik, 2004) and cross-cultural mentoring (Reddick, Griffin, \& Cherwitz, 2012) concepts to help Latino men find and sustain meaningful relationships with those who have the experience and knowledge to help them. College male mentors also need to demonstrate vulnerability to students and openly discuss times when they employ help-seeking behaviors so that the learned behavior of not asking, participating, getting involved, or asking for help can be modified.

Also, the university within this study was an elite, research-intensive institution with a competitive college admissions process, and several of these students were underprepared for the academic challenges that were ahead of them. In order to assist Latino men students in coping with their academics, administrators may want to review policies regarding the level of tutoring and other academic supports available and consider the possibility of enhanced academic advising. Services, possibly with an emphasis on accessing students through culturally congruent, institutionally sponsored groups (e.g., Latino Engagement Center), may facilitate and normalize help seeking. Intrusive advising for classes that tend to be large and impersonal may also mitigate help avoidance and encourage men to find peer study groups. Improvements in these policies have the potential to relieve a modicum of academic stress by providing a firmer 
Journal Committed to Social Change on Race and Ethnicity | 2016

floor of academic support. This, in turn, would help students cope with academic obstacles.

Finally, the Latino men in this study generally favored responses that enabled them to cope internally rather than externally. Given the complicated nature of masculinity and cultural implications for Latino men to manifest a strong, unwavering existence in the face of obstacles (Saenz et al, 2013), coping with academic and social obstacles becomes complicated. Scholars should consider the implications of this research to the institutional and greater social environment in which these Latino men find themselves. Although Latino men may learn how to cope successfully with such academic and social obstacles, stakeholders should consider why Latino men should be forced to cope with these issues in the first place. By more fully understanding the coping responses of Latino men, institutions of higher education may be better equipped to address the array of academic and social obstacles that these students encounter so that eventually we may move beyond the discussion of coping with such obstacles and towards enhancing opportunities for the educational success of these men.

Table 1

List of Latino Men Participants

\begin{tabular}{|l|l|l|l|l|l|}
\hline \multicolumn{1}{|c|}{$\begin{array}{c}\text { Student } \\
\text { Pseudonym }\end{array}$} & $\begin{array}{l}\text { Participation } \\
\text { Type }\end{array}$ & \multicolumn{1}{|c|}{ Class } & \multicolumn{1}{|c|}{ Major } & $\begin{array}{c}\text { College } \\
\text { Generational } \\
\text { Status }\end{array}$ & \multicolumn{1}{|c|}{ Origins } \\
\hline 1. Alberto & $\begin{array}{l}\text { Interview; } \\
\text { Focus Group }\end{array}$ & Senior & Liberal Arts & First & Mexican \\
\hline 2. Antonio & Interview & Senior & Liberal Arts & First & Mexican \\
\hline 3. Arturo & Interview & Junior & Economics & First & Mexican \\
\hline 4. Caesar & $\begin{array}{l}\text { Interview; } \\
\text { Focus Group }\end{array}$ & Senior & Liberal Arts & Second & Mexican \\
\hline 5. Carlos & $\begin{array}{l}\text { Interview; } \\
\text { Focus Group }\end{array}$ & Sophomore & Business & First & Columbian \\
\hline
\end{tabular}


Journal Committed to Social Change on Race and Ethnicity | 2016

\begin{tabular}{|l|l|l|l|l|l|}
\hline 6. Enrique & $\begin{array}{l}\text { Interview; } \\
\text { Focus Group }\end{array}$ & Senior & Mathematics & First & Mexican \\
\hline 7. Estani & Interview & Senior & Engineering & First & Mexican \\
\hline 8. Gilberto & $\begin{array}{l}\text { Interview; } \\
\text { Focus Group }\end{array}$ & Junior & Business & Second & Mexican \\
\hline 9. Josue & Interview & Senior & Business & First & Mexican \\
\hline 10. Mark & Interview & Senior & Engineering & First & Mexican \\
\hline
\end{tabular}

\section{References}

Anzaldua, G. (2012). Borderlands/la frontera: The new mestiza ( $4^{\text {th }}$ ed.). San Francisco, CA: Aunt Lute.

Bandura, A. (2010). Self-efficacy: The exercise of control. New York: Freeman.

Barajas, H. L., \& Pierce, J. L. (2001). The significance of race and gender in school success among Latinas and Latinos in college. Gender \& Society, 15(6), 859878.

Bradbury-Jones, C., Sambrook, S., \& Irvine, F. (2009). The phenomenological focus group: An oxymoron? Journal of Advanced Nursing, 65(3), 663-671.

Bukoski, B. E. \& Hatch, D. K. (2015). "We're still here...We're not giving up": Black and Latino men's narratives of transition to community college. Community College Review. Pre-published December 31. doi: 10.1177/0091552115621385 Cammarota, J. (2004). The Gendered and Racialized Pathways of Latina and Latino Youth: Different Struggles, Different Resistances in the Urban Context. Anthropology \& Education Quarterly, 35, 1, 53-74

Carter, D. F., Locks, A. M., Winkle-Wagner, R., \& Pineda, D. (2006, April). "From when and where I enter": Theoretical and empirical considerations of minority students' transition to college. Paper presented at American Educational Research Association annual meeting, San Francisco, CA.

Cavazos, J., Johnson, M.B., \& Sparrow, G.S. (2010). Overcoming personal and academic challenges: Perspectives from Latina/o college students. Journal of Hispanic Higher Education, 9(4), 304-316.

Compas, B. E. (1998). An agenda for coping research and theory: Basic and applied developmental issues. International Journal of Behavioral Development, 22, 231-237. 
Journal Committed to Social Change on Race and Ethnicity | 2016

Covarrubias, R. \& Stone, J. (2014). Self-monitoring strategies as a unique predictor of Latino male student achievement. Journal of Latinos and Education, 14(1), 5570.

Coyne, J.C. \& Lazarus, R. S. (1980). Cognitive style, stress perception, and coping. In I. L Kutash \& L.B Schlesinger (Eds.) Handbook on stress and anxiety: Contemporary knowledge, theory, and treatment (pp. 144-158). San Francisco, CA: Jossey-Bass.

Creswell, J. (2013). Qualitative inquiry and research design: Choosing among five approaches $\left(3^{\text {rd }}\right.$ ed). Thousand Oaks, CA: Sage.

Davison-Aviles, R. M., Guerrero, M. P., Barajas-Howarth, H., \& Thomas, G. (1999).

Perceptions of Chicano/Latino students who have dropped out of school. Journal of Counseling \& Development, 77, 465-473.

Edwards, L. M., \& Romero, A. J. (2008). Coping with discrimination among Mexican American descent adolescents. Hispanic Journal of Behavioral Sciences, 30, 24-39.

Excelencia in Education. (2015). The Condition of Latinos in Education: 2015 Factbook. Washington, D.C.: Excelencia in Education

Folkman, S., \& Lazarus, R. S. (1980). An analysis of coping in a middle-aged community sample. Journal of Health and Social Behavior, 21, 219-239.

Folkman, S. \& Moskowitz, J.T. (2000). Positive affect and the other side of coping. American Psychologist, 647-654

Ford, D. (1996). Reversing underachievement among gifted Black students: Promising practices and programs. New York, NY: Teachers College.

Fordham, S., \& Ogbu, J. (1986). Black students' school success: Coping with the "burden of acting White." The Urban Review, 18(3), 176-206.

Gandara, P., \& Contreras, F. (2009). The Latino education crisis: The consequences of failed social policies. Cambridge, MA: Harvard University.

Gloria, A., Castellanos, J., Scull, N., \& Villegas, F. (2009). Psychological Coping and Well-Being of Male Latino Undergraduates. Hispanic Journal of Behavioral Sciences, 31, 3, 317-339. 
Journal Committed to Social Change on Race and Ethnicity | 2016

Grantham, T. C., \& Ford, D. Y. (2003). Beyond self-concept and self-esteem for African American students: Improving racial identity improves achievement. High School Journal, 87, 4-7.

Halx, M. D., \& Ortiz, M. (2011). Voices of Latino male high school students on their disconnect with education: Perspectives of "drop-outs" and those on the brink. Latino Studies, 9(4), 416-438.

Harper, S. R., \& Harris, F., III. (2010). College men and masculinities: Theory, research, and implications for practice. San Francisco, CA: Jossey-Bass.

Harper, S. R. (2008). Realizing the intended outcomes of brown: High-achieving African American male undergraduates and social capital. American Behavioral Scientist, 51, 1030-1053. doi:10.1177/0002764207312004

Huerta, A.H. \& Fishman, S.F. (2014). Marginality an Mattering: Urban Latino Male Undergraduates in Higher Education. Journal of The First-Year Experience \& Students in Transition, 26(1), 85-100.

Huerta, A. H., McDonough, P. M., \& Allen, W. R. (2014).“You can go to college”: Understanding masculinity and college identity construction for young men of color. Manuscript submitted for publication.

Hurtado, S., Carter, D. F., \& Spuler, A. (1996). Latino student transition to college: Assessing difficulties and factors in successful college adjustment. Research in Higher Education, 37(2), 135-157.

Hurtado, S., Milem, J., Clayton-Pederson, A. R., \& Allen, W. R. (1998). Enhancing campus climates for racial/ethnic diversity: Educational policy and practice. The Review of Higher Education, 27(3), 279-30

Hycner, R. H. (1999). Some guidelines for the phenomenological analysis of interview data. In A. Bryman \& R. G. Burgess (Eds.), Qualitative research (Vol. 3, pp. 143164). London, UK: Sage.

Kalsner, L., \& Pistole, M. C. (2003). College adjustment in a multiethnic sample: Attachment, separation-individuation, and ethnic identity. Journal of College Student Development, 44(1), 92-109.

Kitzinger, J. (1994). The methodology of focus groups: The importance of interactions between research participants. Sociology of Health and IIIness, 16, 103-121. 
Journal Committed to Social Change on Race and Ethnicity | 2016

Lazarus, R. S. (1981). The stress and coping paradigm. In C. Eisdorfer, D. Cohen, A. Kleinman, \& P. Maxim (Eds.), Models for clinical psychopathology (pp. 177214). New York, NY: Spectrum.

Lazarus, R. S. (2000). Toward better research on stress and coping. American Psychologist, 55, 665- 673.

Lazarus, R. S. \& DeLongis, A. (1983). Psychological stress and coping in aging. American Psychologist, 38, 245-254.

Lazarus, R. S. \& Folkman, S. (1984a). Coping and adaptation. In W. D. Gentry (Ed.), The handbook of behavioral medicine (pp. 282-325). New York, NY: Springer.

Lazarus, R. S. \& Folkman, S. (1984b). Stress, appraisal, and coping. New York, NY: Springer.

Lazarus, R. S., Kanner, A. D., \& Folkman, S. (1980). Emotions: A cognitivephenomenological analysis. In R. Plutchik \& H. Kellerman (Eds.), Theories of emotion (pp. 189-217). New York, NY: Academic Press.

Levant, R. F., \& Kopecky, G. (1996). Masculinity reconstructed: Changing the rules of manhood- at work, in relationships and in family life. New York, NY:

Plume/Penguin.

Lu, C. (2015). Finding los cientificos within: Latino male science identity development in the first college semester. Journal of College Student Development. 56(7), 740745.

Maxwell, J. (2013). Qualitative research design: An interactive approach ( $3^{\text {rd }}$ ed.). Thousand Oaks, CA: Sage.

Moustakas, C. (1994). Phenomenological research methods. Thousand Oaks, CA: Sage.

Nuñez, A. M (2009). Latino students' transitions to college: A social and intercultural capital perspective. Harvard Education Review, 79(1), 22-48.

Padilla-Diaz, M. Phenomenology in educational qualitative research: Philosophy as science or philosophical science? International Journal of Educational Excellence, 1(2), 101-110. 
Journal Committed to Social Change on Race and Ethnicity | 2016

Phinney, J. S., \& Haas, K. (2003). The process of coping among ethnic minority firstgeneration college freshmen: A narrative approach. Journal of Social Psychology, 14, 707-726.

Pierce, G. R., Sarason, I. G., Sarason, B. R. (1996). Coping and social support. In Zeidner, M., \& Endler, N. S. (Eds.), Handbook of coping (pp. 434-451). New York: Wiley.

Reddick, R.J., Griffin, K.A., Cherwitz, R.A. (2012). What you get when you give: How graduate students benefit from serving as mentors. Journal of Faculty Development, 26(1), 37-49.

Saenz, V. B., Bukoski, B.E., Lu, C., \& Rodriguez, S. (2013). Latino males in community college: A phenomenological study of masculinity constructs and their effect on college experiences. Journal of African American Males in Education 4(2), 82102.

Saenz, V. B., Mayo, J., Miller, R. \& Rodriguez, S. L. (2015). (Re)defining masculinity through peer interactions: Latino men in Texas community colleges. Journal of Student Affairs Research and Practice, 52(2), 164-175.

Saenz, V. B., \& Ponjuan, L. (2009). The vanishing Latino male in higher education. Journal of Hispanic Higher Education, 8(1), 54-89. doi: 10.1177/1538192708326995

Saenz, V. B. \& Ponjuan, L. (2011). Men of color: Ensuring the academic success of Latino males in higher education. Institute of Higher Education Policy. Retrieved from http://www.ihep.org/assets/files/publications/mr/\%28Brief\%29_Men_of_Color_Latinos.pdf

Seidman, I. (1998). Interviewing as qualitative research: A guide for researchers in education and the social sciences. New York: Teachers College Press.

Solorzano, D., Villalpando, O., \& Oseguera, L. (2005). Educational inequities and Latina/o undergraduate students in the United States. Journal of Hispanic Higher Education, 4(3), 272-294.

Somerfield, M. R., \& McCrae, R. R. (2000). Stress and coping research: Methodological challenges, theoretical advances, and clinical applications. American Psychologist, 55, 620 25. 
Journal Committed to Social Change on Race and Ethnicity | 2016

Suarez-Orozco, C., \& Suarez-Orozco, M. (1995). Transformations: Migration, family life, and achievement motivation among Latino adolescents. Stanford: Stanford University Press.

U.S. Census Bureau (2012). Population Division, 2012 National Population Projections, Table 4: Projections of the Population by Sex, Race, and Hispanic Origin for the United States: 2015 to 2060, 2012.

van Emmerik, J. H. (2004). The more you can get the better: Mentoring constellations and intrinsic career success. Career Development International, 9(6), 578-594.

Xuereb, S. (2015). Academic resourcefulness, coping strategies, and doubting in university undergraduates. Journal of Further and Higher Education 39(2), 205222.

Zalaquett, C. P. (2006). Study of successful Latina/o students. Journal of Hispanic Higher Education, 5, 35-47.

Zalaquett, C. P., \& Feliciano, P. (2004). The Latino student success stories research: Providing role models to Latino students. SAEOPP Journal, 21, 7-22.

Zarate, M. E., \& Gallimore, R. (2006). Gender Differences in Factors Leading to College Enrollment: A Longitudinal Analysis of Latina and Latino Students. Harvard Educational Review, 75, 4, 383-408 